\title{
Erratum to: Using Natural-Kind Essentialism to Defend Dispositionalism
}

\section{Travis Dumsday}

Published online: 26 September 2013

(C) Springer Science+Business Media Dordrecht 2013

\section{Erratum to: Erkenn (2013) 78:869-880 \\ DOI 10.1007/s10670-012-9361-z}

Due to a regrettable oversight on my part, the proper 'acknowledgements' section was not included in this article as originally published. That section should have read as follows.

Acknowledgements This paper was written during a post-doctoral fellowship at UNC Chapel Hill, funded by the Social Sciences and Humanities Research Council (SSHRC). I would like to express my thanks to the government and taxpayers of Canada for this generous financial support. Sincere thanks are also due to my supervisor at UNC, Marc Lange, for his valuable comments on multiple drafts.

The online version of the original article can be found under doi:10.1007/s10670-012-9361-z.

T. Dumsday $(\bowtie)$

Philosophy \& Religious Studies, Livingstone College, 701 West Monroe St., Salisbury,

NC 28144, USA

e-mail: tdumsday@livingstone.edu 